\section{Professional Socialization from the Perspective of Female Surgeons: Challenges and Career Achievements}

\author{
Socialização Profissional sob a Ótica de Cirurgiãs: Desafios e Realização na \\ Carreira Profissional
}

\author{
Isabelle Christine Oliveira dos Santos ${ }^{10}$ \\ Tereza Cristina Batista de Lima ${ }^{1}$ ๑ \\ Luis Eduardo Brandão Paiva ${ }^{1}$ \\ Davi Sampaio Marques ${ }^{1}$ (อ \\ Elidihara Trigueiro Guimarães ${ }^{1}$ [อ
}

\section{ABSTRACT}

Objective: aiming to contribute to the field of investigation on the association between work and gender, the study focuses on the medical surgeon profession, which has a low female participation rate. Thus, the aim of the study is to understand how professional socialization of female surgeons occurs, with an emphasis on gender and work relationships. Methods: this is a qualitative, descriptive study, comprising in-depth interviews carried out with 10 female surgeons, assessing their perceptions about the analysis categories belonging to the theoretical model of professional socialization: the looking-glass self, the establishment of duality, and the adjustment of the self-concept. Results: the interviewees' greatest interest in the surgical area originated from personal characteristics they thought were important to a surgeon, in addition to the desire to solve the patient's problem in a more practical and objective way. Conclusions: we observed that there are conflicts between the lay and professional culture and that the professional insertion was characterized by challenges, such as prejudice and difficulties in reconciling the personal and professional aspects of life. The study increased the understanding of how the job market incorporated the female surgeons, since it is a predominantly male area characterized by many stereotypes.

Keywords: career; diversity; gender; prejudice; professional socialization.

1. Universidade Federal do Ceará, Fortaleza, CE, Brazil

Cite as: Santos, I. C. O., Lima, T. C. B., Paiva, L. E. B., Marques, D. S., \& Guimarães, E. T. (2021). Professional socialization from the perspective of female surgeons: Challenges and career achievements. Revista de Administração Contemporânea, 25(4), el80303. https://doi.org/10.1590/1982-7849rac2021 180303.en

\section{RESUMO}

Objetivo: com o intuito de contribuir para o campo de investigação do conhecimento da relação entre o trabalho e o gênero, o estudo póe em foco a profissão de médico cirurgiáo, que conta com baixa participação feminina. Assim, o objetivo do estudo é compreender como ocorre a socializaçáo profissional de médicas cirurgiãs, com ênfase no gênero e nas relações de trabalho. Métodos: é uma pesquisa de natureza qualitativa, de caráter descritivo, com entrevistas em profundidade realizadas com 10 médicas cirurgiâs, examinando suas percepçôes em torno das categorias de análise pertencentes ao modelo teórico da socialização profissional: passagem através do espelho, instalação da dualidade e ajuste da concepção de si. Resultados: o interesse maior das entrevistadas pela área cirúrgica partiu de características de personalidade que se julgavam importantes a um cirurgiáo, além do desejo de resolver o problema do paciente de forma mais prática e objetiva. Conclusóes: verificou-se que existem conflitos entre a cultura leiga e a profissional e que a inserção profissional foi marcada por desafios, como preconceitos e dificuldades na conciliação da vida pessoal e profissional. A pesquisa ampliou a compreensão de como as cirurgiâs estáo inseridas no mercado de trabalho, área predominantemente masculina e caracterizada por muitos estereótipos.

Palavras-chave: carreira; diversidade; gênero; preconceito; socialização profissional.

JEL Code: J16, J44, M14

Editor-in-chief: Wesley Mendes-Da-Silva (Fundação Getulio Vargas, EAESP, Brazill) Reviewers: Amalia Pérez-Nebra ( Centro Universitário de Brasilia, Brazil) (1) One of the reviewers chose not to disclose his/her identity. Peer Review Report: The Peer Review Report is available at this external URL.

Received: November 16, 2018 Last version received: August 07, 2020 Accepted: August 10, 2020

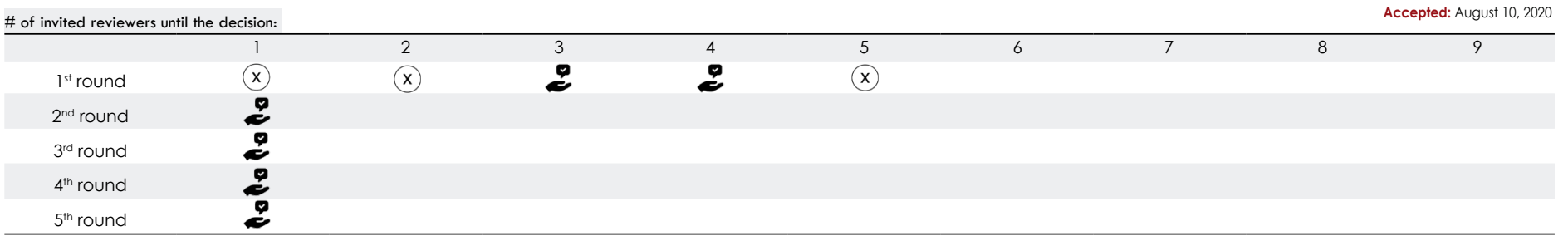




\section{INTRODUCTION}

Workforce diversity has become a strategy for organizations, with a direct impact on the achievement of organizational goals (Alves \& Galeão-Silva, 2004; Ashikali \& Groeneveld, 2015; Pereira \& Hanashiro, 2010; Saraiva \& Irigaray, 2009). Organizations that explore individual differences in their staff composition can gain in competitiveness, productivity, skill diversity, organizational growth, and innovation (Bedi, Lakra, \& Gupta, 2014; Cho, Kim, \& Mor Barak, 2017).

In the context of gender diversity, Fitzsimmons (2012) emphasizes that organizations with equal policies for men and women can have better performance and capacity for problem solving. Thus, women's performance in the labor market has been gaining space, especially since the 20th century and with more emphasis in the 21st century (Leslie, Manchester, \& Dahm, 2017; Vale, Serafim, \& Teodósio, 2011; Zauli, 2015). In Brazil, for instance, the increase of the female population is directly aligned with the inclusion of women in the labor market, as well as with the expansion of schooling and class participation in several sectors of the economy, especially in professions that used to be traditionally characterized by a larger number of men, such as Medicine, Engineering, Architecture, and Law (Andreassi \& Tonelli, 2018; Scheffer \& Cassenote, 2013).

Saraiva and Irigaray (2009), Zauli (2015), Póvoa, Maffezzolli, Pech and Silva (2017) and Fine, Sojo and Lawford-Smith (2020) consider that gender differences still exist in the labor market. Women earn lower wages, are less likely to achieve high hierarchical positions in organizations, and have their capacities undervalued in professions dominated by male representativeness, considered to be stereotyped - professions and/or occupations considered to be masculine, which hold male references - , which is explained by the construction of the gender in social role theory (Chies, 2010).

Regarding the stereotyped professions, which are traditionally characterized by the presence of men, it is worth mentioning Medicine, which despite the increasing feminization in Brazil, has not changed the fact that it is a profession predominantly characterized by a greater number of men. Over the years, however, women have progressed and broken barriers, increasingly becoming part of the medical field; however, this has not changed the fact that it is still a masculine occupation (Scheffer, Biancarelli, \& Cassenote, 2015).

The stereotypes in Medicine are more evident when evaluating the specialties in the medical area. Of the 53 specialties, 38 are dominated by men, with the majority of females being restricted to specialties such as pediatrics and dermatology, which are medical areas with a greater tradition of women's participation (Broadhead, 2017; Scheffer et al., 2015). From this perspective, Table 1 shows a comparison of the number of medical specialties by gender based on data from the demographic profile of the first medical demographic analysis carried out in Brazil, in 2011, and the most recent medical demography published in 2018. The surgical medical specialties still show a greater number of men but increases in the percentages of women have been observed in almost all mentioned areas. These data increase the relevance of the discussion about the presence of this audience in these niches and their careers.

Overall, the biggest discrepancies in female representation are found in surgical specialties, as they are traditionally dominated by men, and often require more physicalstrength andendurance(Lempp \& Seale, 2006). The specialties in which there is a greater female participation, such as dermatology, endocrinology, and pediatrics, have also increased this representativeness. However, a woman's decision to become a surgeon may involve more obstacles, challenges, and difficulties than that of a man, as there is more discrimination against female doctors, as they are women, especially in surgical specialties (Cochran et al., 2013; Franco \& Santos, 2010; Seemann et al., 2016).

Considering the abovementioned facts and focusing on gender and work relationships, as in the case of female surgeons, and taking into consideration the phases of professional socialization established by Hughes (1958) and Dubar (2005, 2012) - the lookingglass self, the establishment of duality, and the adjustment of the self-concept - , the following question arises: how does the female surgeons' professional socialization occur? This study aims to understand how the professional socialization process of female surgeons takes place.

Professional socialization is a topic that has been significantly discussed in academia, both nationally and internationally. Thus, after carrying out a search in scientific journal databases, such as Web of Science, Scopus, Spell, and Scielo, we found a low incidence of studies on the professional socialization of female surgeons, the reasons that lead women to enter this specialty area, and how this process takes place. Therefore, it is relevant to understand how female doctors are inserted in the labor market, an area still characterized by many stereotypes - aiming to gain knowledge about the processes of professional socialization and their careers, mainly to disrupt the strong and persistent male stereotypes of the 'male surgeon' profession.

Thus, the study seeks to contribute to the scientific knowledge between work relationships through professional socialization and gender in stereotyped 
Table 1. Medical specialties amount comparison between men and women in Brazil in 2011 and 2018.

\begin{tabular}{|c|c|c|c|c|c|c|}
\hline Specialty & Female (2011) & Male (2011) & Total (2011) & Female (2018) & Male (2018) & Total (2018) \\
\hline Cardiovascular surgery & $110-10 \%$ & $992-90 \%$ & 1,102 & $215-10.4 \%$ & $1,847-89.6 \%$ & 2,062 \\
\hline Hand surgery & $27-13.4 \%$ & $175-86.6 \%$ & 202 & $118-16.1 \%$ & $614-83.9 \%$ & 732 \\
\hline Head and neck surgery & $53-13.8 \%$ & $331-86.2 \%$ & 384 & $172-17.6 \%$ & $805-82.4 \%$ & 977 \\
\hline Digestive tract surgery & $91-8.6 \%$ & $964-91.4 \%$ & 1,055 & $274-10.3 \%$ & $2,382-89.7 \%$ & 2,656 \\
\hline General surgery & $2,206-16.2 \%$ & $11,400-83.8 \%$ & 13,606 & $6,447-21 \%$ & $24,321-79 \%$ & 30,768 \\
\hline Pediatric surgery & $294-32.5 \%$ & $611-67.5 \%$ & 905 & $527-40.7 \%$ & $768-59.3 \%$ & 1,295 \\
\hline Plastic surgery & $799-19.9 \%$ & $3,213-80.1 \%$ & 4,012 & $1,294-23.3 \%$ & $4,249-76.7 \%$ & 5,543 \\
\hline Thoracic surgery & $32-6.5 \%$ & $459-93.5 \%$ & 491 & $85-9.5 \%$ & $811-90.5 \%$ & 896 \\
\hline Vascular surgery & $331-17.7 \%$ & $1,543-82.3 \%$ & 1,874 & $916-23.3 \%$ & $3,022-76.7 \%$ & 3,938 \\
\hline Dermatology & $3,731-72.7 \%$ & $1,400-27.3 \%$ & 5,131 & $6,053-77.1 \%$ & $1,797-22.9 \%$ & 7,850 \\
\hline $\begin{array}{l}\text { Endocrinology and } \\
\text { metabology }\end{array}$ & $1,631-63.9 \%$ & $921-36.1 \%$ & 2,552 & $3,480-70.4 \%$ & $1,461-29.6 \%$ & 4,941 \\
\hline Endoscopy & $266-25.2 \%$ & $789-74.8 \%$ & 1,055 & $873-29.1 \%$ & $2,126-70.9 \%$ & 2,999 \\
\hline Neurosurgery & $168-8.2 \%$ & $1,902-91.8 \%$ & 2,071 & $248-8.6 \%$ & $2,638-91.4 \%$ & 2,886 \\
\hline Pediatrics & $19,052-70 \%$ & $8,170-30 \%$ & 27,222 & $27,451-74.2 \%$ & $9,542-25.8 \%$ & 36,993 \\
\hline Urology & $38-1.2 \%$ & $3,215-98.8 \%$ & 3,253 & $108-2.2 \%$ & $4,819-97.8 \%$ & 4,927 \\
\hline
\end{tabular}

Note. Source: Made by the authors based in Scheffer, M., Biancarelli, A., \& Cassenote, A. (2011). Demografia médica no Brasil: Dados gerais e descriçóes de desigualdades: Relatório de pesquisa. São Paulo: Conselho Regional de Medicina do Estado de São Paulo, Conselho Federal de Medicina; and Scheffer, M., Biancarelli, A., \& Cassenote, A. (2018). Demografia médica no Brasil 2018. São Paulo: Departamento de Medicina Preventiva, Faculdade de Medicina da Universidade de Sáo Paulo, Conselho Regional de Medicina do Estado de São Paulo, Conselho Federal de Medicina.

professions, characterized by the significant presence of men when compared to that of women, as in the case of physicians who work as surgeons (Franco \& Santos, 2010; Seemann et al., 2016). Moreover, investigations in the field of professional socialization scientific knowledge, in general, are carried out without looking for specific niches, and so this investigation focuses on an occupation that remains little explored in academic literature (Hughes, 1958; Shinyashiki, Mendes, Trevizan, \& Day, 2006; Zarshenas et al., 2014), allowing advances in this field of scientific knowledge and giving a pioneering and original characteristic to the study.

In addition to this introduction, we divided the article into five more sections. The second section contains a contextualization in the medical area, considering female surgeons. Then, the professional socialization is explained based on its three phases: the looking-glass self, the establishment of duality, and the adjustment of the self-concept. In the fourth section, we discuss the methodological procedures adopted to obtain the results. Subsequently, there is the analysis and discussion of the results. Finally, in the sixth section, we highlight the final considerations of the study, with reflections for future studies on the topic.

\section{FEMALE SURGEONS: PROFESSIONAL INSERTION AND PRACTICE}

The medical profession has been growing in Brazil due to the increase in the offer of vacancies in medical schools, the growing needs of the population, and the healthcare system expansion. However, studies indicate that female doctors, in certain specialties, face discrimination just because they are women (Cochran et al., 2013; Edmunds et al., 2016; Seemann et al., 2016), receive lower salaries than their male counterparts (Scheffer et al., 2015; Seemann et al., 2016), have difficulties with professional advancement (Mckimm, Silva, Edwards, Greenhill, \& Taylor, 2015; Schroen, Brownstein, \& Sheldon, 2004; Seemann et al., 2016) have difficulties in reconciling professional and personal life (Cech, 2013; Edmunds et al., 2016; Franco \& Santos, 2010; Miller \& Clark, 2008), and are minorities in many medical specialties (Scheffer et al., 2015).

Edmunds et al. (2016) point out that female representation in Medicine is low due to discrimination, prejudice, and concerns about the balance between work and private life. Scheffer, Biancarelli and Cassenote (2015) state that, even with the expansion of Medicine in Brazil and its feminization, it is still an area harboring stereotypes that dictate 
characteristics, values, and attitudes, as well as determining which specialties are more directed at men or women. Some highly stereotyped specialties and without considerable female representation in the job market are those related to the surgical area (Franco \& Santos, 2010; Seemann et al., 2016).

Starting with the selection process for medical residency, women are subjected, in many cases, to gender discrimination, as the selection process is considered to be very competitive in medical schools. Moreover, women who choose to dedicate themselves more to reconciling work and family life, as well as motherhood, are often seen by teachers and mentors as individuals who tend not to go through the careful screening in the selection process for residency or post-graduation in the medical field (Mason \& Ekman, 2007; Minella, 2017).

Seemann et al. (2016) show that the greatest challenges faced by female surgeons arise because they are women and the more they advance in their careers, the more noticeable it becomes. In addition, blackmail, harassment, defamation, and ridicule have been present in the evolution of women in Medicine, particularly in surgery, and more severely and consistently at the beginning of their careers as surgeons (Cochran et al., 2013; Franco \& Santos, 2010).

According to Seemann et al. (2016), a female mentoring can be beneficial for the career, not only professionally, but to help find the balance between the career and the personal and family life. Therefore, there is a tendency for women to give up the surgical specialty in the first years of their careers, mainly due to the combination of sexual discrimination and the scarcity of female mentors in surgery (Cochran et al., 2013). However, professional satisfaction among female surgeons is considered high, and most of them would choose to be a surgeon again, also recommending continuing the medical career in specialties that deal directly with surgery (Schroen et al., 2004; Seemann et al., 2016).

\section{PROFESSIONAL SOCIALIZATION}

Dubar (2005) highlights that, in addition to the transmission of values, norms, and rules, socialization is a process that builds the individual's identity, identification, and a sense of belonging in society, which implies belonging to a group, and guides the individual's personal and professional attitudes (Broadhead, 2017; Santos, 2005; Spudeit \& Cunha, 2016). The socialization encompasses the construction, deconstruction, and reconstruction of identities that are formed throughout people's lives (Dubar, 2005).

According to Boulart and Lanza (2007), the construction of an identity is a flexible, continuous process that is influenced by the social environment, while it is influenced and modified by the subjects. The construction and deconstruction of the 'self' is determined by the acceptance or rejection of the social and cultural influences that the individuals encounter throughout life. Work activities give meaning to the individual existence and organize life in society, called 'trades,' 'vocations,' or 'professions,' and such activities allow personal fulfillment and social recognition (Dubar, 2005; 2012).

The professional individual is built not only through theoretical and abstract knowledge acquired during academic training, but also, and particularly, with the initiation of the actual work, in which occurs a conversion of what students expected from the profession and the stereotypes they had of such profession into the actual professional world in practice, with all its activities, prestigious, and dirty, as well as its specific culture (Dubar, 2012; Gazaway, Gibson, Schumacher, \& Anderson, 2019; Hughes, 1958).

Medical education encompasses a series of processes by which medical culture is kept alive through time and generations, being disseminated in different ways among doctors and lay people (Hughes, 1958). Lay individuals, before entering the medical environment, already have previous knowledge of this culture, with conceptions of the physician's role and beliefs about Medicine. Thus, the initial period of professional insertion is when two cultures interact within the individual: the lay and the professional one. As the individuals progress and insertion occurs in the professional culture through training and practice, they start to acquire the required skills, the roles to be played, the tasks to be performed, and the positions they can attain, and they also adjust their conceptions of self, their aptitudes, tastes, capacity, with discoveries about their career (Dubar, 2012; Hughes, 1958).

In the medical profession, the career path follows a well-known sequence: pre-medical phase, medical student, medical intern, medical resident, practicing physician, and specialist (Cruess, Cruess, Boudreau, Snell, \& Steinert, 2015; Hughes, 1958). The career paths taken involve many risks, as they contain a set of projections of oneself in the future, and the change from one activity to another implies the possibility of loss of skills, which can cause anxiety in the individuals, and, consequently, allowing considerations regarding their choice of career lines (Hughes, 1958). Hughes' professional socialization model has three phases; and Dubar (2005, 2012), based on the results found by Hughes (1958), named them: the looking-glass self, the establishment of duality, and the adjustment of the self-concept (Table 2). 
Table 2. Phases of professional socialization.

\begin{tabular}{ll}
\hline $\begin{array}{l}\text { The looking-glass } \\
\text { self }\end{array}$ & $\begin{array}{l}\text { First moment of the individual's professional insertion. This is the phase in which the individual has the lay culture of } \\
\text { the profession and is faced with the professional culture, and then both interact within the individual, causing emotion } \\
\text { and discomfort. }\end{array}$ \\
$\begin{array}{l}\text { The establishment } \\
\text { of duality }\end{array}$ & $\begin{array}{l}\text { Phase in which there is a confrontation between the preconceptions the individual had of his profession versus the } \\
\text { reality found during the performance of activities, when one is faced with the difficulties and the multiplicity of tasks } \\
\text { related to the profession, some more prestigious and others less so. Students have a simpler prior conception of the } \\
\text { required skills than the reality. This is a moment of conflicts, crises, and discoveries. }\end{array}$ \\
$\begin{array}{l}\text { The adjustment of } \\
\text { the self-concept }\end{array}$ & $\begin{array}{l}\text { Last phase and the moment when the professionals, after confronting the lay culture with the professional reality and } \\
\text { the conflicts caused by the transition, find an adjustment and start to build their careers. In this phase, the individuals } \\
\text { make discoveries about themselves and about the paths they want to take in their careers. }\end{array}$
\end{tabular}

Note. Source: created by the authors based on Hughes, E. C. (1958). Men and their work. Florence, MA: Free Press.; Dubar, C. (2005). A socialização: Construçấo das identidades sociais e profissionais. São Paulo: Martins Fontes.; Dubar, C. (2012). A construçâo de si pela atividade de trabalho: A socialização profissional. Cadernos de pesquisa, 42(146), 351-367. https://doi.org/10.1590/S0100-15742012000200003

Although this division into phases conveys a sequential idea, Hughes (1958) observes that there is no end stop, as professionals must be frequently evolving, and their identities are in constant construction and reconstruction.

\section{RESEARCH METHOD}

\section{Participants}

This research is characterized by being a qualitative, descriptive study - considering the perception of female surgeons about professional socialization. It is noteworthy that this investigation, based on the perceptions of the research subjects, constitutes a methodological choice capable of contributing to the debate on the feminization of the medical career, especially those who work as surgeons. The research sample consisted of female surgeons who work in the city of Fortaleza, state of Ceará, Brazil - a city with a wide incidence rate and representativeness regarding the number of female surgeons in Brazil. The state of Ceará, according to data from the last medical demographic analysis carried out in 2018, has 12,652 registered doctors, of which $57.2 \%$ are men and $42.8 \%$ are women. In Fortaleza, the capital of the state of Ceará, the percentage of women has already increased to $45.8 \%$, close to the national average (45.6\%). Regarding the number of specialists, in all 13 surgical areas that are professionally recognized, or that involve surgery, men are the majority; even in General Surgery, which is one of the basic specialties, women comprise only one fifth of the total number of professionals.

According to data from the Inter-Union Department of Statistics and Socioeconomic Studies
(Departamento Intersindical de Estatística e Estudos Socioeconômicos [DIEESE], 2017), the average monthly earnings of men and women, considering the real and dollar currencies, related to the quotation for the year 2016, are equivalent to $\mathrm{R} \$ 1,473$ (US\$ 452.04) and $\mathrm{R} \$$ 1,115 (US\$342.18), respectively, with women receiving the equivalent of $75.7 \%$ of the average monthly income received by men. Regarding the rate by worked hour, a male professional's hourly wage decreased from $\mathrm{R} \$ 8.06$ (US\$ 2.06) to R 8.00 (US\$2.45) from 2015 to 2016, but still remained higher than a female professional's hourly wage, which is R $\$ 6.51$ (US\$2.00), equivalent to $81.4 \%$ of the male professional's. Considering this inequality, in general terms, a closer look at the reality of women, especially female surgeons in the assessed city, is justified.

We carried out the selection of the interviewees using the snowball technique, a sampling technique that uses reference chains (Atkinson \& Flint, 2001; Creswell, 2007), so that the first female surgeons who were interviewed indicated new respondents until saturation occurred in their speeches, which was observed in the interviews.

A total of ten surgeons were interviewed, divided into the following specialties: two are ophthalmic surgeons, two are coloproctologist surgeons, two are digestive tract surgeons, one is a liver transplant surgeon, one is a vascular surgeon, one is an otorhinolaryngologist surgeon, and one is a trauma-orthopedic surgeon, all identified under the title 'Surgeon' followed by a number from 1 to 10 , aiming to facilitate the nomenclature of the interviewees and preserve their respective identities, which guarantees the professionals' confidentiality and anonymity during the performed investigation (Table 3). 
Table 3. Characterization of the interviewees.

\begin{tabular}{|c|c|c|c|c|c|}
\hline Interviewee & Surgical subspecialty & Age & $\begin{array}{l}\text { Length of time } \\
\text { working as a } \\
\text { surgeon }\end{array}$ & Marital status & Children \\
\hline Surgeon 01 & $\begin{array}{l}\text { Ophthalmology - glaucoma and } \\
\text { cataract surgery }\end{array}$ & 40 & 15 years & Married & 3 \\
\hline Surgeon 02 & General surgery — coloproctology & 38 & 10 years & Divorced & 2 \\
\hline Surgeon 03 & General surgery — digestive system & 42 & 20 years & Married & 0 \\
\hline Surgeon 04 & General surgery - liver transplant & 37 & 10 years & Married & 2 \\
\hline Surgeon 05 & Trauma-orthopedic surgery & 55 & 30 years & Widowed & 3 \\
\hline Surgeon 06 & General surgery - coloproctology & 48 & 22 years & Married & 2 \\
\hline Surgeon 07 & $\begin{array}{l}\text { Otorhinolaryngology - surgery } \\
\text { and clinic }\end{array}$ & 42 & 18 years & Married & 3 \\
\hline Surgeon 08 & Vascular surgery and general surgery & 34 & 7 years & Married & 0 \\
\hline Surgeon 09 & Ophthalmology — retinal surgery & 32 & 7 years & Married & 0 \\
\hline Surgeon 10 & General surgery — digestive system & 35 & 8 years & Single & 0 \\
\hline
\end{tabular}

Note. Source: adapted by the authors.

\section{Instrument}

The interview script was structured into two blocks: the first comprising questions related to the sociodemographic profile, such as age, specialty, length of professional experience, among others; and the second refers to the phases of professional socialization, established by Hughes (1958) and Dubar (2005, 2012), namely: the looking-glass self, the establishment of duality, and the adjustment of the self-concept.

\section{Data collection procedure}

We carried out the data collection through indepth interviews, with the aid of a semi-structured script. We recorded these interviews after prior authorization from the participants, carrying it out from November to December 2017, totaling 5 hours, 5 minutes, and 11 seconds of recording.

\section{Analysis procedure}

Using the content analysis technique, which allows analyzing the communications that describe the content of the messages through orderly and objective procedures (Bardin, 2011), we verified the analysis categories (the three phases of professional socialization), based on the research by Hughes (1958), which were defined by Dubar $(2005,2012)$ (Table 4).
We carried out a lexical analysis during the content analysis, considering that the software used - Atlas.ti 7, which makes it possible to encode, classify, and manage the data from semi-structured interviews - aimed at encoding, grouping, and counting the frequency of the content analysis dimensions. Thus, we carried out an analysis for the content and context of the answers provided by the female surgeons, which depicts the depth of the interviewees' actual speech.

Aiming to treat the data qualitatively in a methodologically structured manner, thus bringing greater reliability and validity to the obtained results, we encoded the interviewees' citations based on the literature. Subsequently, we interpreted the results through content analysis, being validated according to the categories of analysis covered in the empirical and conceptual literature, defined by Dubar $(2005,2012)$ and based on the study by Hughes (1958).

Finally, based on this software, we used the Network View tool, since the context units and their respective registration units are connected through arrows, and so each code is reflected in an ordered pair $\{x-y\}$, where ' $x$ ' represents the frequency of the registration unit, the number of citations to which the code was related, and ' $y$ ' is the density of the code, which is related to the number of the other codes to which it is associated. 
Table 4. Analysis categories, context units, and registration units.

\begin{tabular}{|c|c|c|}
\hline Analysis categories & Context units & Registration units \\
\hline \multirow[t]{13}{*}{ The looking-glass self } & \multirow[t]{6}{*}{ Interests } & The surgical practice itself \\
\hline & & Desire \\
\hline & & Parents' example \\
\hline & & Immediate results \\
\hline & & Delight \\
\hline & & Personality \\
\hline & \multirow[t]{4}{*}{ Skills } & Manual skills \\
\hline & & Resolutivity \\
\hline & & Objectivity \\
\hline & & Other personal characteristics \\
\hline & \multirow[t]{3}{*}{ Insertion } & Sexism \\
\hline & & Adversities \\
\hline & & Facility \\
\hline \multirow[t]{18}{*}{ The establishment of duality } & \multirow[t]{3}{*}{ Idealization } & Known profession \\
\hline & & More peaceful life \\
\hline & & Success \\
\hline & \multirow[t]{3}{*}{ Reality } & Non-surgical overwork \\
\hline & & Conditions \\
\hline & & Dislocation \\
\hline & \multirow[t]{5}{*}{ Difficulties } & Prejudice \\
\hline & & Reconciliation \\
\hline & & Workload \\
\hline & & Hierarchy \\
\hline & & Underemployment \\
\hline & \multirow[t]{7}{*}{ Annoyances } & Tiredness \\
\hline & & Structure \\
\hline & & Multiple roles \\
\hline & & Unpredictable schedules \\
\hline & & Surgical complications \\
\hline & & Consolidation in the labor market \\
\hline & & Specific procedures \\
\hline \multirow[t]{11}{*}{ The adjustment of the self-concept } & \multirow[t]{4}{*}{ Abandoning stereotypes } & Little union between coworkers \\
\hline & & Late recognition \\
\hline & & Remuneration \\
\hline & & Gender differences \\
\hline & \multirow[t]{3}{*}{ Professional identity } & Femininity \\
\hline & & Intrinsic characteristics \\
\hline & & Multitasking \\
\hline & \multirow[t]{4}{*}{ Career } & Domestic duties \\
\hline & & Glass ceiling \\
\hline & & Ambitions \\
\hline & & Satisfaction \\
\hline
\end{tabular}

Note. Source: adapted by the authors. 


\section{ANALYSIS AND DISCUSSION OF RESULTS}

We sought to verify how the professional socialization of female surgeons occurs, according to the categories of analysis: the looking-glass self, the establishment of duality, and the adjustment of the self-concept (Hughes, 1958).
The general configuration of the analysis categories and context and registration units obtained in the analysis of the speech of the 10 interviewed female surgeons are detailed based on each of the phases of professional socialization.

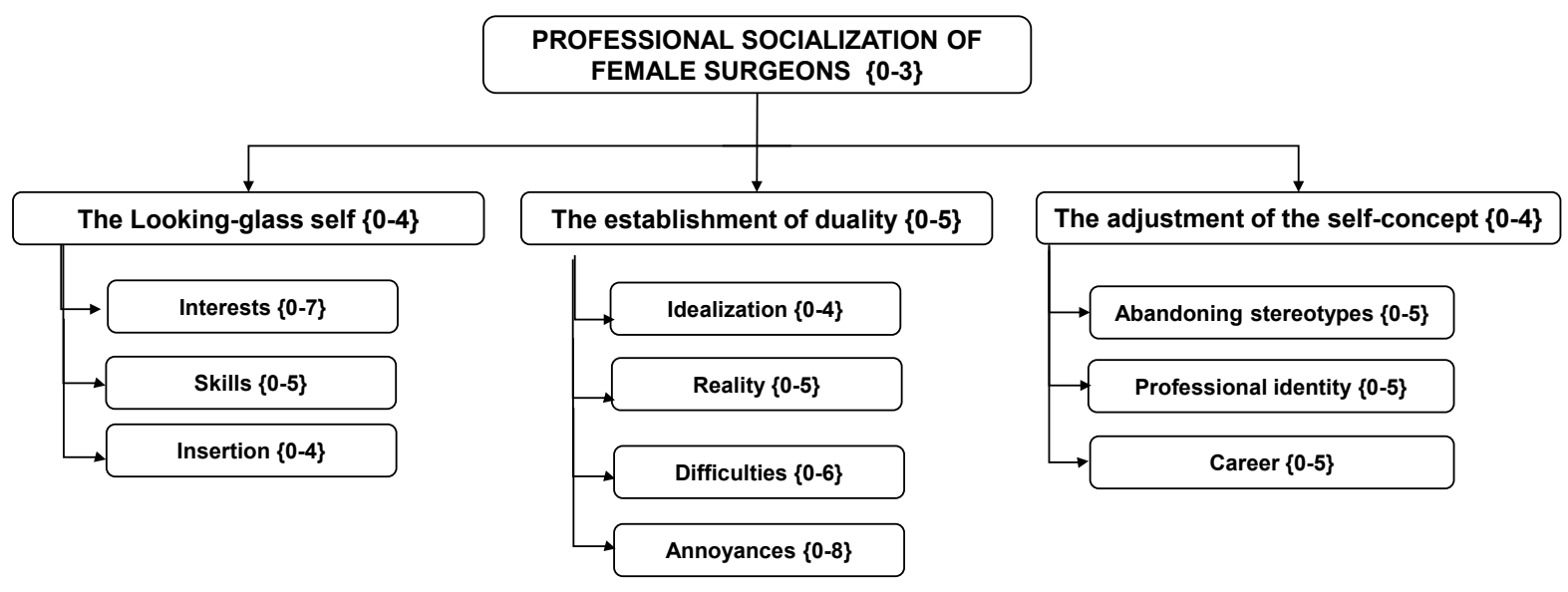

Figure 1. Relationship between analysis categories and context and registration units.

Source: research data.

\section{The looking-glass self}

In order to understand how this phase of the surgeons' socialization occurred, we established three context units: interests, skills, and insertion. The first context unit to be observed is the unit of interests, related to the interest in the profession.

The responses were varied, as each surgeon mentioned several reasons for her interest, but the personality factor was the one that was most often repeated in their speeches, with eight citations. For the female surgeons, the fact that they have certain personality characteristics was decisive for their interest and choice for the surgical specialty: "I am very active, so I could not imagine myself working only at the office" (S5); “... I saw that I had always been a very objective person, that I could really face performing a surgery and it would really work" (S6). These personality characteristics corroborate what was stated by Bellodi (2004), that the 'surgeon' profession represents a person who is brave, anxious, objective, and immediatist.
Another factor that is often mentioned by the female surgeons is the surgical practice itself. Six surgeons mentioned they were interested in surgery because they liked the surgical environment and the surgical process, with which they had contact during medical school or residency, according to surgeon 2: “... I decided that I was going to study surgery because of what I saw in experimental surgery, through the practice of surgery" (S2).

The surgeons also mentioned the matter of immediate results at six moments. According to them, the fact of being able to act directly on the patient's disease and obtain fast results aroused their interest: “... when you give some medicine to the patient you do not expect it to have an immediate effect, you have to wait until the next day, and that distressed me, because I wanted to solve that situation right away, and the surgery lets you do that, right?" (S4). That is in line with what was reinforced by Bellodi (2004), about the desire to be inserted into this specialty, which occurs due to the wish to help people in a practical and resolutive way. 


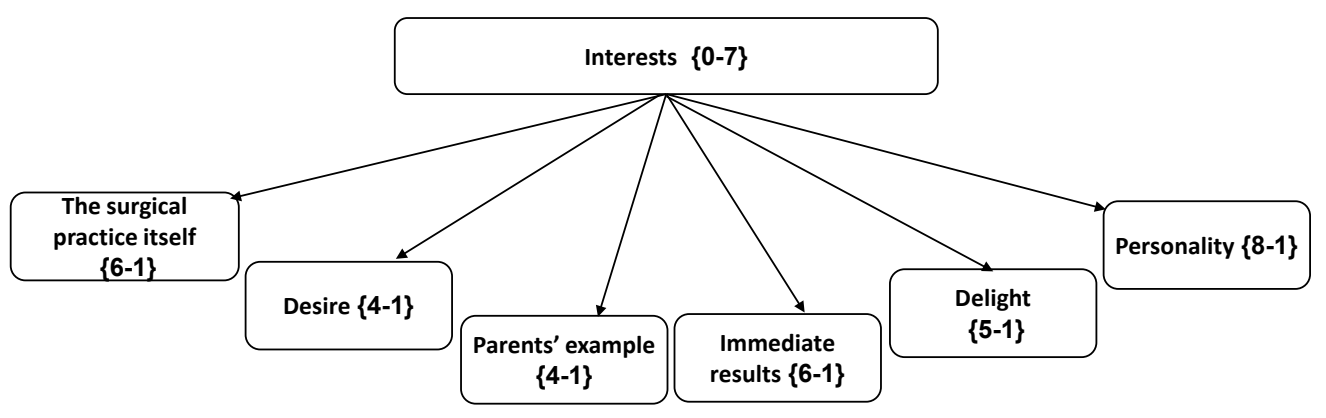

Figure 2. The looking-glass self — interests.

Source: research data.

The surgeons mentioned the registration unit 'delight' five times during their speeches, showing love and appreciation for the profession: "... the surgeon changed the destiny of some patients and that delighted me a lot" (S6). Four surgeons also mentioned that they were interested in surgery due to the example of their parents who were also surgeons, whom they admired: "I believe I was greatly influenced by my father; my father was a doctor and a surgeon and I always admired him a lot for his profession, the way he spoke, how he treated ..." (S6).

Moreover, four surgeons mentioned that they chose to become surgeons because they desired it, because they always wanted it and knew that this is what they wanted to do, which can be seen in the following excerpt: "I think I wanted to study surgery since the beginning, I started medical school and already wanted to study surgery and I definitely ended up wanting to study surgery" (S6).

The second context unit concerns skills, which lists the skills that surgeons had and identified as necessary ones.

Thus, it can be observed that the most often mentioned skill was resolutivity, as found in the following speech: "the wish to treat the patient more quickly, to have the opportunity to offer this treatment option" (S3). Another point that the female surgeons frequently mentioned was manual skills, as surgeons 1 and 3 state: "you must have surgical skills in both your right and left hands, because it helps you" (S1); "I like the manual skill of performing a surgical procedure. I always liked manual activities a lot" (S3).

The factor of other personal characteristics included, in turn, other skills that the female surgeons had and considered important for surgery, such as: theoretical and practical knowledge (S2), discipline (S3), separate the work from the emotional aspect (S3), and being active (S4). Objectivity was mentioned five times as a skill that the surgeons though they had, as pointed out below: “... surgeons think very objectively, you know, so you have that one, it is resolved this way and that way, we do not 'phosphorylate' a lot thinking about a and b ... I was always very objective" (S8).

The third unit that we analyzed was insertion, in which there were reports of experiences when they entered the profession.

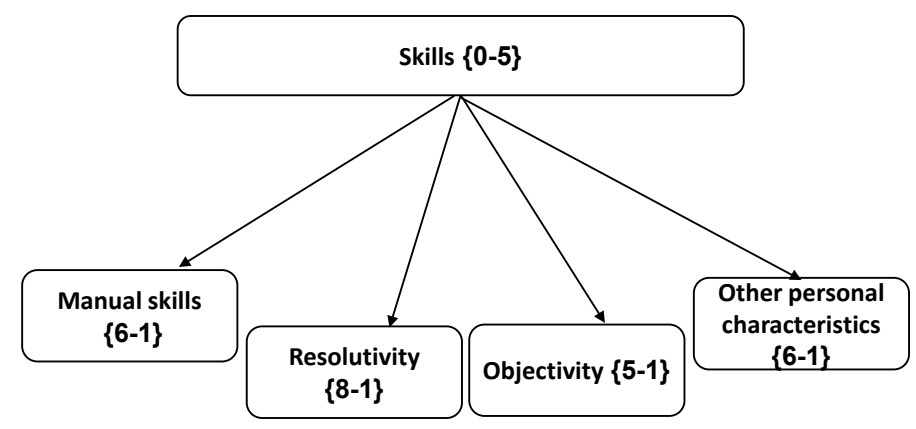

Figure 3. The looking-glass self — skills Source: research data. 


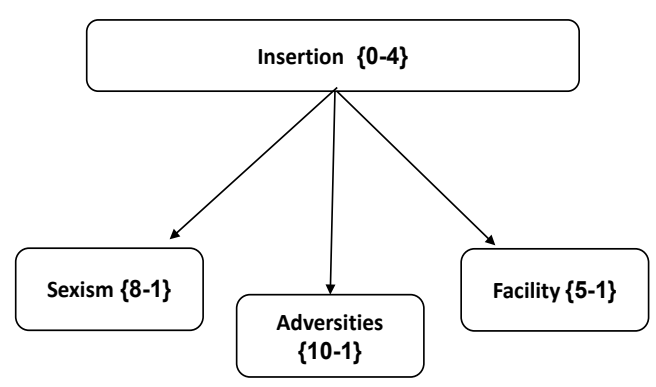

Figure 4. The looking-glass self — insertion.

Source: research data.

The registration unit 'adversity' was the most frequent one, mentioned 10 times. Adversity is understood as the difficulties the interviewees experienced during the insertion period. Among these adversities, we mention: few clientele, machismo, maternity, saturated job market, among others: "look, in the beginning it is very difficult. It is more difficult in the first year, because we think it will not work ..." (S1).

The sexism factor was the second most often mentioned, considering the experience of the insertion in the surgical profession, with eight mentions. Sexism is understood as the insertion problems faced by women due to their sex or gender: "... it is more a matter of prejudice, of not believing that the cute, young woman is capable, you know, because being a surgeon is a male thing" (S4). This corroborates what was emphasized by Hill and Vaughan (2013) and Seemann et al. (2016), who point out the prejudice and difficulties faced by women during the insertion of a field dominated by professional know-how associated to so-called male skills.

The last registration unit insertion is the facility, which the surgeons mentioned five times reporting that they were happy in their professional insertion, either because they were welcomed by the surgical teams or because they entered a more indefinite market niche: "I was very lucky, honestly, I never had any difficulty regarding professional insertion, contrary to what everyone thought" (S3).
Therefore, it was observed that the female surgeons had previous interests and skills related to the profession. The factor that most influenced them to be interested in the area was related to their personalities' characteristics; and the skill that most of them believed they had was resolutivity. However, the professional insertion disclosed, in most speeches, the adversities they found when facing the professional surgeon's culture.

\section{The establishment of duality}

To understand how this phase of socialization occurred, we sought to establish how the female surgeon sees her profession, based on four context units: idealization, reality, difficulties, and annoyances.

In the idealization unit, the factor most often mentioned by the interviewees as an idealized profession model was success, which was chosen to include positive factors in a surgeon's career, associated to: many patients, pleasure, acknowledgement, good remuneration, and glamor. According to the following speech, "... you have that false idea that surgery is just the glamor of operating, of being there and operating and the satisfaction of operating" (S10). The results are in accordance with the studies by Bellodi (2004), according to whom the surgical profession is seen as well paid and one that has social prestige.

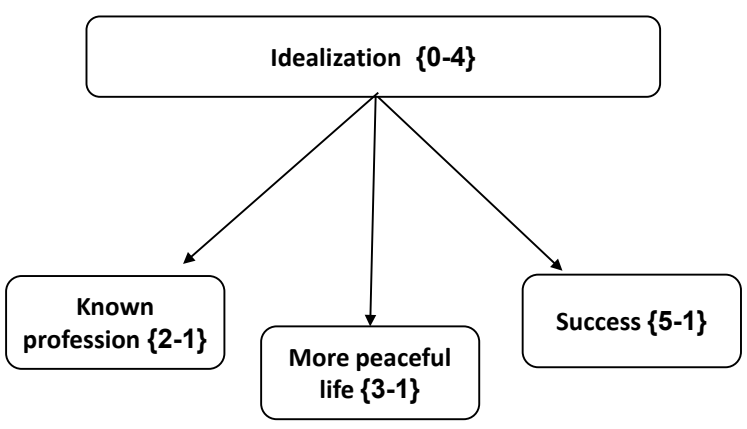

Figure 5. The establishment of duality — idealization.

Source: research data. 
Another mentioned unit was a more peaceful life, a term used to encompass free time: "I wanted to have a little more free time, but you do not have that, right? (laughs)" (S1); “... you know that you will have your time taken up by the profession, but you cannot imagine how much" (S2).

The other registration unit was the fact that it was a known profession, which depicts the experience of two female surgeons who mentioned they already knew about the profession due to family members who were surgeons, and so they knew exactly what to expect; thus, they did not have idealizations, as they already knew the reality: "I think I already imagined it, because I knew the surgical environment since the beginning of medical school, and I have doctors in the family, and some are surgeons, so I knew what the profession was like" (S3).

The reality context unit focuses on finding out the interviewees' opinion about the reality encountered during the activities related to the profession. As a result, the following registration units were found: non-surgical overwork, which was mentioned five times, dislocations, mentioned four times, and conditions, mentioned three times.

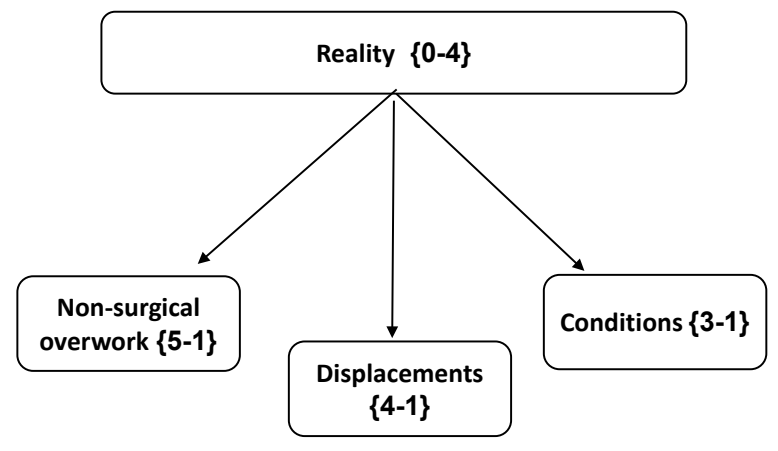

Figure 6. The establishment of duality — reality.

Source: research data.

Non-surgical overwork means the activities that are complementary to surgical ones, such as pre- and postoperative responsibilities, constant patient monitoring, bureaucratic activities, and ward activities: "I had no idea how much time you have to dedicate to the ward, surgery, office activities ...” (S2).

Another factor mentioned was dislocations, in which, according to surgeons, traveling between several hospitals and their other activities of the working day is a task that affects the quality of life: "... the surgeon has to go from one hospital to another, on some days we must go to three, four different hospitals, so that becomes quite hard" (S8). And by conditions, they mean the lack of materials, professionals, and an adequate work environment in some hospitals: “... the emergency room bothers me ... 'you have to operate on this patient now - Ah, you cannot operate because there is no anesthesiologist ... because there is no room or material" (S4).

In addition, to understand the female surgeons' perception of their profession, we asked them about the difficulties they faced and still face in their profession. To analyze the 'difficulties' context unit, five registration units were identified.

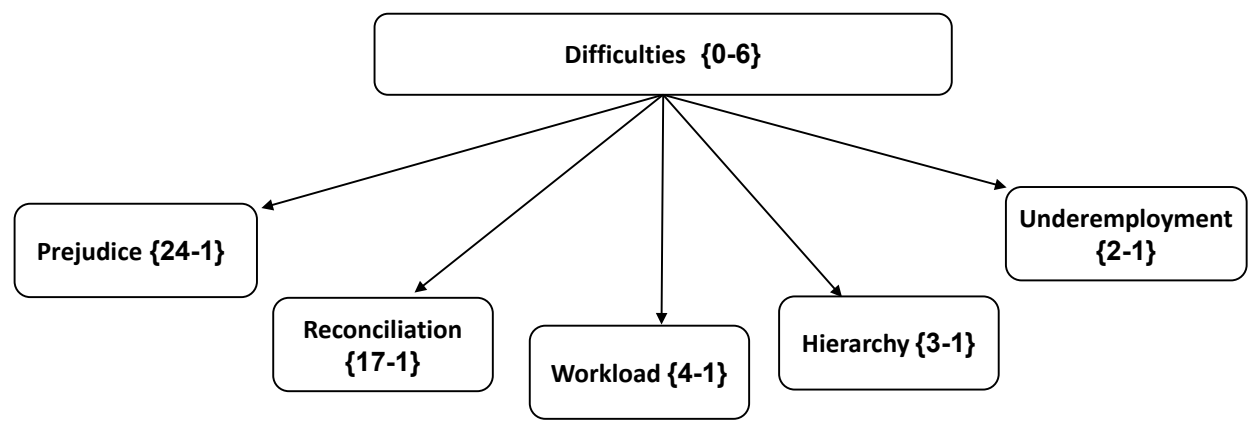

Figure 7. The establishment of duality — difficulties.

Source: research data. 
The most significant unit, mentioned twentyfour times, was prejudice. This result corroborates that emphasized by Hill e Vaughan (2013), who report on the prejudice and challenges faced by female doctors in the surgical area, even before they choose the specialty, during their medical training. One of the biggest difficulties faced by a female surgeon is prejudice, related to both gender and age, and even birthplace, by colleagues, supervisors, and patients: "I had staff that did not accept women and did not offer support to residents" (S6).

The surgeons reported that the profession is still seen by society as a male profession: "because I am a woman, definitely, because there is prejudice, they think that men are better than us" (S1); "the patients show the greatest prejudice, you know, because you are a woman. Many times, I am on duty, I arrive, and the patient says: 'Where's the (male) doctor?' Right? (laughs)" (S5).

The interviewees also said they have to prove they are good surgeons to their colleagues and patients: “... it is not common, you know? To see a woman operating. So, when you operate ... it is like you have to prove that you know how to do it" (S9). Zauli (2015) indicates that this fact occurs due to the stereotyped idea in society that the male professional is better and more competent, as well as due to the existence of patriarchal social norms that exist and are often imposed in society.

In addition to reports of gender bias, there were also reports of age bias; some of the female surgeons said they felt the patients were uncomfortable because they were women and young. Other surgeons reported that they felt more uncomfortable because of the age issue: “... nobody thinks that I can operate: 'dang,' do you operate? Do you operate the retina? - People act like that: you, a young woman, are you not scatterbrained? (laughs)" (S9). Surgeon 7 reported that she felt prejudice not only for being a woman, but because she was from the Northeast, when she was attending residency in São Paulo: “... perhaps a veiled prejudice, like for being a woman and from the Northeast, I perceived that ... but I always tried to compensate with more study and more work, right? Then ... I think I had a good response" (S7).

Other interviewees also reported that they experienced situations of gender jokes and pranks, but that they did not consider them as prejudice and were not offended by those. According to Franco and Santos (2010), the prejudice against female surgeons was more severe at the beginning, involving defamation, blackmail, and ridicule, but it is still present in a veiled and disguised form in some jokes: "... but that was never a direct thing, you know, never said in a threatening tone, it was much more like a joke, that you end up hearing, ... so there is this weight, this pressure" (S9).

Two of the surgeons emphasized that, as much as they knew prejudice existed, they did not suffer it, so for them that was not a difficulty, as they reported: "no, I never felt discrimination, really. When I talk to some colleagues, they say 'because I am a woman, I suffer discrimination'; I honestly did not notice it" (S9).

During the analysis of the difficulties faced by the female surgeons, another registration unit was mentioned seventeen times: reconciliation, which refers to the reports of the problems faced by women when trying to reconcile their career with their personal life, especially regarding the care of their children. The female surgeons reported they suffer professional losses when they need to stop working during maternity leave and because they were not able, or cannot dedicate so much quality time to the family: "it is more difficult to reconcile the life of a surgeon with the life of a mother, a homemaker ... The doctor cannot be sick, the doctor cannot have a sick child ..." (S4). This corroborates what was stated by Seemann et al. (2016), that female surgeons have difficulties in reconciling their professional and academic activities with family life, as well as that stressed by Oliveira, Cavazotte and Paciello (2013), that there are difficulties in reconciling family and work when the job responsibilities start to interfere in the fulfillment of family obligations.

The workload is an indicated difficulty, in which the surgeons reported that they work too much and have little free time for other activities, mainly during the residency: "the difficulty is just because, willingly or not, we work too much, right?" (S4). Another difficulty is the hierarchy, about which three female surgeons said that the profession is a very hierarchical one: "surgery is very hierarchical ... and there is still the old model of that angry surgeon that spits fire and rules with an iron fist ..." (S2).

Finishing the difficulties context, the last registration unit identified was underemployment, mentioned by two surgeons as a difficulty they faced in their profession: “... I spent eleven years working here at the hospital, underemployed, with a very low salary for [company name] just so I could have my space here ..." (S3).

The context unit 'annoyances' showed the following registration units (Figure 8). 


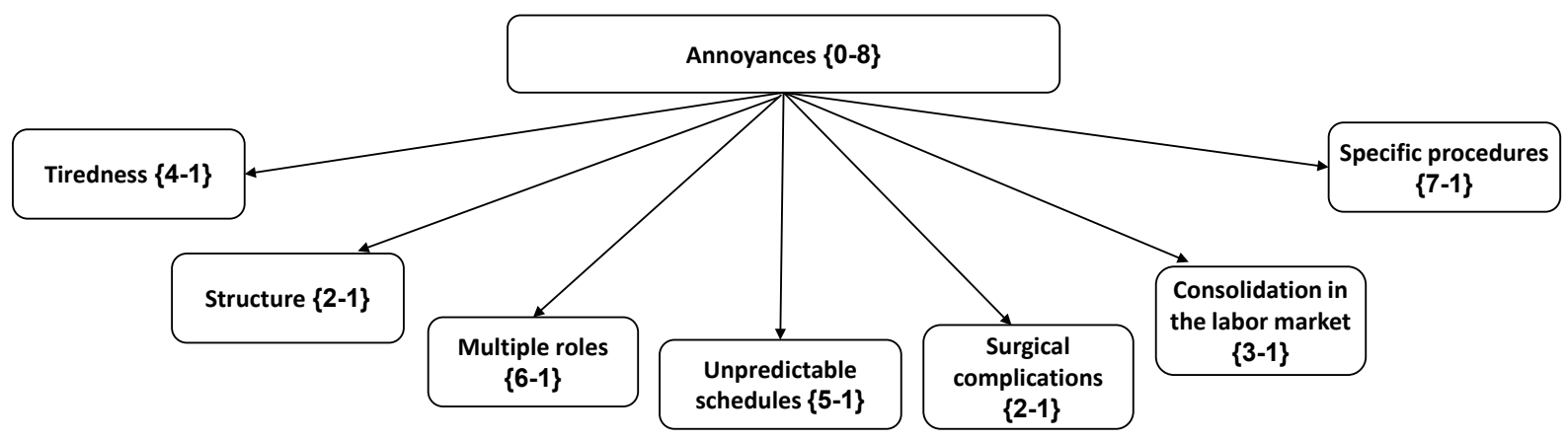

Figure 8. The establishment of duality — annoyances.

Source: research data.

The specific procedures unit refers to specific procedures, mentioned by the surgeons, as annoyances, such as surgeries and activities they do not like or do not feel capable of doing: "when I worked at [hospital], what also bothered me in the emergency room was to perform amputations, I always hated doing amputations ... I really did not like it, because I thought it was such a severe mutilation" (S4). Additionally, another emphasized: "I did not like to do... it was flaps, microsurgery, I did not like it, I worked very little with skin" (S5).

Another factor was the multiple roles, which are related to the reconciliation unit. The interviewees reported being uncomfortable having to divide themselves between the multiple roles: "I wanted more [from the profession] but it is already accepted that I cannot have more than I already have, because my other side comprises being a mother and wife" (S4).

The third most often mentioned registration unit for annoyances was the unpredictability of schedules, mentioned five times. The surgeons reinforced that they have to spend the entire day out of home, do not have time to eat meals, and work even on their days off: "it is time, lack of time, it is leaving the house at sixthirty in the morning and returning at nine o'clock at night and sometimes having to leave again ...” (S8). The unpredictability of schedules in surgical work and the lack of time mentioned by the female surgeons summarize the results of the research by Schroen, Brownstein and Sheldon (2004), in which female surgeons state that their working hours do not leave them enough time for their personal and family life. These results corroborate the findings by Edmunds et al. (2016), who highlight that one of the conditions that most push women away from a medical career is the lack of balance between the time spent in their professional and personal activities.
Moreover, tiredness was pointed out by the female surgeons as an annoyance in their routines, as these are tiring due to the fact that they need to stand for several hours during the surgical procedures and because they need to go to several hospitals during the day: "... we have to go to four, five hospitals during the day, with the type of traffic we have here, it is something that tires you during your routine" (S10).

Surgeons also identified the following as annoyances: consolidation in the job market, mentioned three times; surgical complications, mentioned twice; and structure, also mentioned twice. According to Surgeon 8 , the consolidation in the job market does not occur so fast: "the difficulty that everyone faces when you begin working at the office is advertisement, being recognized, and a patient indicates another, that takes a little while, right?" For Surgeon 7, the surgical complications they had at the beginning of their careers were annoyances and were responsible for her decision to stop operating.

It can be observed that surgeons had idealizations of the profession, with the success factors being the most often mentioned ones. The reality most often faced in the profession is that of non-surgical overwork and constant dislocations.

The greatest difficulties faced by the surgeons are prejudice and reconciliation with the other roles they assume. The biggest annoyances in the surgeons' routine is performing specific procedures mentioned by them and not being able to perform them the way they would like for all the roles they assume. Although some surgeons affirm they already knew about the profession and there were no surprises during their insertion, they still find conflicts between idealizations and the reality they found. 


\section{The adjustment of the self-concept}

For this category of analysis, we established three context units: the abandoning of stereotypes, professional identity, and career.

Regarding the abandoning of stereotypes, the most often mentioned registration units were gender differences and remuneration, both mentioned three times. The interviewees had the concept that there were not so many gender differences in the profession, but verified that it occurs: "my initial perception was that I, as a woman, could be the same as any man ... I thought women and men were equal; today I do not think they are the same, I am sure they are not" (S4).

As for the remuneration, the speeches indicate that the surgeons' earnings have declined: "over the years, we surgeons have been earning less, so it is not like that, oh, a paradise, you do not have a huge income, you are not rich, you work a lot to have a worthy, reasonable salary, to have a good life like that" (S3). The term late recognition was mentioned at two moments, raising the question that they thought that recognition would come easier than it did: "so you have to be very good at what you do to be able to stand out. I thought that recognition would come easier" (S1). The last registration unit for the abandoning of stereotypes was the union between coworkers, which was mentioned by Surgeon 1, who raised the issue of rivalry: "... I thought that perhaps the group would be more cohesive, the group of surgeons and doctors would be more unified, but if you fool yourself, if you are, between quotations, 'innocent,' you end up having problems, you know?”

In the context unit 'professional identity,' we highlight three registration units: intrinsic characteristics, mentioned eight times; femininity, mentioned seven times; and multitasking, mentioned once.

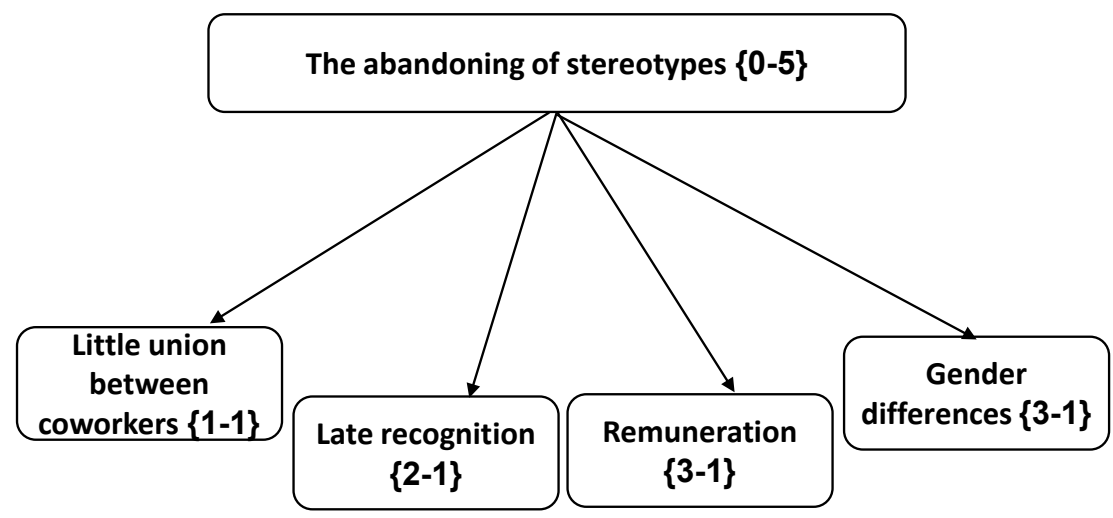

Figure 9. The adjustment of the self-concept — the abandoning of stereotypes.

Source: research data.

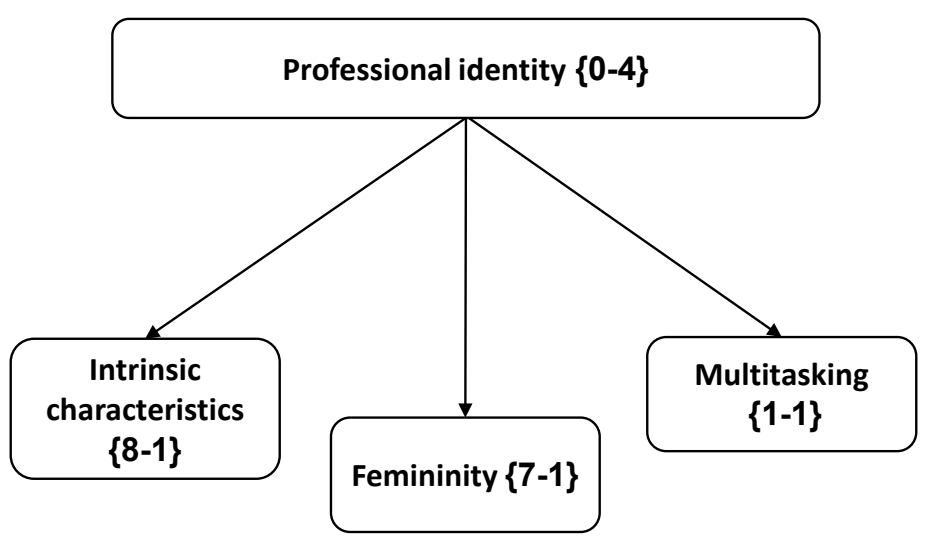

Figure 10. The adjustment of the self-concept — professional identity. Source: research data. 
Intrinsic characteristics are understood as all adjectives mentioned in an attempt to characterize what a surgeon is: “... generally, the surgeon's profile and especially of female surgeons must have this profile of being determined, being strong, of not thinking that the male figure could intimidate her" (S6); "I will confess something to you: when I see a female surgeon, I see her through different eyes. I see grit, I see strength ... because she really overcame her inner barriers" (S5).

Femininity means being feminine, dressing up, abandon the protective layer of masculinization that was once necessary to be accepted in the profession: “... I always liked to dress up, since the time of internship I go to the hospital wearing high heels and makeup" (S8); “... I was always very serious, nowadays I am much more relaxed than I was before ...” (S3). Although the personality of the female surgeons is aligned with the perspective of Bellodi (2004), that they are courageous, objective, and immediatist, in this aspect, the fact that their femininity stands out does not mean they do not have a personality that includes male stereotypes.

To finish this context unit, one surgeon mentioned that her professional identity is to be multitasking - a woman who is a good professional and at the same time is a good mother and a good wife, according to the speech of Surgeon 4: “... I know few female surgeons that are now in my age group, who perform surgeries, who work a lot, but also give more support to their families, right?"

In the career context unit, we sought to identify the surgeons' perception of their careers as women.

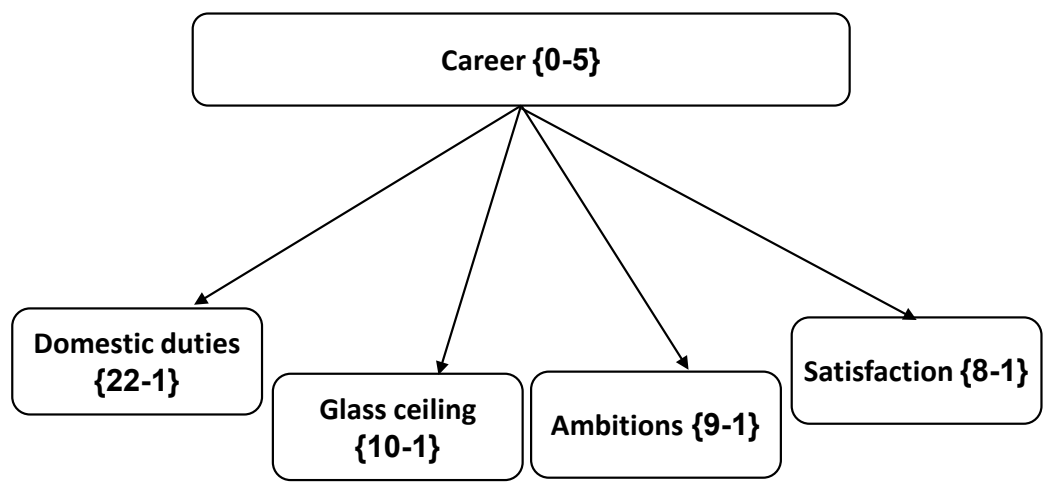

Figure 11. The adjustment of the self-concept — career.

Source: research data.

The most representative registration unit, throughout the speech of surgeons in the career context, was domestic duties, in which their speeches were pooled, reporting that domestic duties are the main reason for the low female representativeness in the surgical career, as well as an obstacle to the growth of the female surgeon in her career. As observed in their speeches, many women need to choose to dedicate themselves to either family or career success: “... I am stuck regarding my career, right? I am leaving it stagnant as a personal option until my children grow up a little bit" (S4). Such results confirm the research by Franco and Santos (2010), who emphasize that forming a family affects women's careers much more than those of men, since the concept that raising children and taking care of the home are female activities still persists (Oliveira, Cavazotte, \& Paciello, 2013; Vale et al., 2011; Zauli, 2015).

Another registration unit identified in the career was the concept of glass ceiling, referring to the difficulties that women face to ascend in their careers due to gender. Some female surgeons mentioned that they occupy managerial positions, while others reported that they did not because they did not want to, but most recognize the existence of the glass ceiling or have already experienced it, mentioning that there are still functions that are predominantly occupied by men, and that are overlooked in their careers due to the fact that they can get pregnant and have a family: “... perhaps if I were a man in my position, I would have grown more in my career" (S1); "... the question of the glass ceiling is not because 'Ah, she is a woman, she is not fit for that,' this paradigm has changed, right, it is more a question of 'Oh, she is a woman, she will have a family, have a child, how will she do it?" (S2). The results confirm the studies by Schroen et al. (2004) and Seemann et al. (2016), in which female surgeons report that they do not feel they have the same career opportunities as men, in such a way that the number of surgeons at high-level positions does not keep pace with the increase in the total number of women in the profession. 
The career ambitions factor was repeatedly cited by the surgeons, being mentioned nine times, such as getting a $\mathrm{PhD}$, having a teaching career, recognition, taking on representative positions, among others: "what I aspire to is to be valued, to be really recognized by my patients and in my work environment" (S9); “... I want to keep growing, especially in my subspecialty ... improving the work at the office, becoming a well-known name in vascular surgery ...” (S8). It demonstrates the relevance for the ambitions related to socialization (Carvalho, Borges, Vikan, \& Hjemdal, 2011).

The registration unit 'satisfaction' was mentioned eight times, showing that they are satisfied with their choice, that they love their profession and feel professional accomplishment. Thus, the following report stands out: "so, I currently have 18 years of professional activity, and thus, particularly, I am very happy to be like that, regarding my small achievements, and what I set out to do" (S7). Seemann et al. (2016) state that professional satisfaction among female surgeons is high and that most would choose to be a surgeon again.

Finally, it seems that the professional insertion of female surgeons still faces challenges, especially regarding the reconciliation between personal and professional life, as well as the prejudice that still exists for female medical surgeons. Table 5 depicts a summary of the main research findings.

Table 5. Summary of the main research results.

\begin{tabular}{|c|c|c|}
\hline Categories of analysis & Context units & Main results \\
\hline \multirow{3}{*}{ The looking-glass self } & Interests & $\begin{array}{l}\text { The factor that most influenced them to become interested in the area was their personality's } \\
\text { characteristics. }\end{array}$ \\
\hline & Skills & The most important skill they believed they had was resolutivity. \\
\hline & Insertion & $\begin{array}{l}\text { The insertion was characterized, in the majority of the speeches, by adversities encountered when } \\
\text { facing the professional culture of being a surgeon. }\end{array}$ \\
\hline \multirow{4}{*}{$\begin{array}{l}\text { The establishment of } \\
\text { duality }\end{array}$} & Idealization & The success factors were the most often mentioned in this idealization. \\
\hline & Reality & The reality most often found in the profession is non-surgical overwork and constant dislocations. \\
\hline & Difficulties & $\begin{array}{l}\text { The difficulties encountered by female surgeons are prejudice and reconciliation with the other roles } \\
\text { they assume. }\end{array}$ \\
\hline & Annoyances & $\begin{array}{l}\text { The biggest annoyance in the surgeons' routine is performing specific procedures mentioned by them } \\
\text { and not being able to perform the multiple roles they assume the way they would like to. }\end{array}$ \\
\hline \multirow{3}{*}{$\begin{array}{l}\text { The adjustment of the } \\
\text { self-concept }\end{array}$} & $\begin{array}{l}\text { Abandoning of } \\
\text { stereotypes }\end{array}$ & $\begin{array}{l}\text { The abandoning of stereotypes such as the surgeon's very good and fast remuneration, as well as the } \\
\text { idea that there were no gender differences in the profession. }\end{array}$ \\
\hline & $\begin{array}{l}\text { Professional } \\
\text { identity }\end{array}$ & $\begin{array}{l}\text { The identity assumed by the female surgeons includes characteristics that are intrinsic to surgeons, } \\
\text { such as determination, grit, and femininity. }\end{array}$ \\
\hline & Career & $\begin{array}{l}\text { The female surgeons pointed out the glass ceiling and domestic duties as the main obstacles to } \\
\text { professional growth; yet, they declared themselves happy and satisfied with their profession. }\end{array}$ \\
\hline
\end{tabular}

Note. Source: created by the authors.

\section{CONCLUSIONS}

This study sought to understand how the female surgeons' professional socialization process occurs. It was possible, therefore, to perceive this process as being characterized by challenges and obstacles, particularly for surgeons who are mothers and have more years of experience in the labor market. Women who are mothers suffered or suffer more due to unpredictable schedules, problems in reconciling private life with professional life and domestic responsibilities, as well as constantly struggling with having to relegate some of their activities in favor of another. They also face the issue of the glass ceiling with more problems, due to the professional limbo they experience during pregnancy, in addition to the choice of having to face career stagnation to dedicate themselves to their children's early childhood period. 
We observed that surgeons with more years of experience suffered more with the prejudice factor because the insertion occurred at a time when the profession's male stereotype was even stronger, suffered from age prejudice as newcomers to the profession, as well as a more explicit gender bias by a more patriarchal and more traditional society than the current one.

For the younger surgeons, the socialization process has shown to be easier in terms of gender prejudice, as society has been evolving and the role of women being relegated to domestic duties, although still present in society, has increasingly less space. Regarding the reconciliation between work and family, it was observed that the role of being a mother was a major factor in the interviewees' speeches regarding the reasons why women seek this profession less. Additionally, we observed that female surgeons experienced the three phases of socialization of the adopted theoretical model (the looking-glass self, the establishment of duality, and the adjustment of the selfconcept) and that being a surgeon is a challenging but satisfactory profession for women.

This study's main contribution was expanding the understanding of the professional socialization of female surgeons, a group that remains little investigated by researchers from Applied Social Sciences, mainly at the national level. It also contributes to a broader and more accurate perception of women in the labor market, as well as the particularities of this insertion, as we carried out the study with a class of professionals that has a predominantly male representation.

Among some of the limitations that naturally arise during the development of scientific research, especially in the case of women working in professions characterized by male stereotypes, it is worth mentioning the difficulty in finding female surgeons working in certain subspecialties, such as cardiac surgery, neurosurgery, and thoracic surgery, which would be relevant to the study, due to the scarce female participation in these specialties. Moreover, the research included female surgeons from a single Brazilian state, thus not depicting a more representative panorama at the national level. Despite constituting a methodological cut, which gives voice to the main actors of this phenomenon of the feminization of the medical surgeon career, the research presents this restriction of having only the point of view of female surgeons as the analyzed target audience.

Therefore, some suggestions for future studies include: to understand the motivations of young medical students when choosing surgery as a profession and how they perceive this career; to investigate the profession's hazards to the occupational health of these women; extend the issue of work versus family conflict that so many of the surgeons mentioned; and also broaden the scope of this investigation to include surgeons from other cities and states, while also carrying out quantitative research.

Also from the perspective of a research program, we suggest that studies be carried out to investigate the perceptions of male surgeons and patients on the subject, so that the results can be compared with the findings of this research. Finally, considering the scarcity of published studies evaluating this topic, this study can be used as the basis to evaluate other aspects of the relationship between women and work, in addition to analyzing other professions with a predominant presence of men or women, whether in the medical field or in other occupations of similar prestige, such as Engineering and Law, also known as imperial professions in the Brazilian context.

\section{REFERENCES}

Andreassi, T., \& Tonelli, M. J. (2018). Women Entrepreneurs in São Paulo, Brazil. In Entrepreneurial Learning City Regions (pp. 121-136). Chan: Springer.

Alves, M. A., \& Galeão-Silva, L. G. (2004). A crítica da gestão da diversidade nas organizaçóes. $R A E-$ Revista de Administração de Empresas, 44(3), 20-29. https://doi.org/10.1590/S0034-75902004000300003

Ashikali, T., \& Groeneveld, S. (2015). Diversity management for all? An empirical analysis of diversity management outcomes across groups. Personnel Review, 44(5), 757-780. https://doi.org/10.5465/AMBPP.2014.15878abstract
Atkinson, R., \& Flint, J. (2001). Accessing hidden and hardto-reach populations: Snowball research strategies. Social Research Update, 33(1), 1-4. Retrieved from http://sru.soc.surrey.ac.uk/SRU33.html

Bardin, L. (2011). Análise de conteúdo (4th ed). Lisboa: Ediçôes 70.

Bedi, P., Lakra, P., \& Gupta, E. (2014). Workforce diversity management: Biggest challenge or opportunity for 21 st century organizations. Journal of Business and Management, 16(4), 102-107. https://doi.org/10.9790/487X-1643102107 
Bellodi, P. L. (2004). The general practitioner and the surgeon: Stereotypes and medical specialties. Revista do Hospital das Clínicas, 59(1), 15-24. https://doi.org/10.1590/S0041-87812004000100004

Boulart, I. B., \& Lanza, M. B. F (2007). Identidade das pessoas e das organizações. Management in Dialogue Review, 9(1), 1-18. https://doi.org/10.20946/rad.v9i1.1509

Broadhead, R. S. (2017). The private lives and professional identity of medical students. London: Routledge.

Carvalho, V. D., Borges, L. O., Vikan, A., \& Hjemdal, O. (2011). Resiliência e socialização organizacional entre servidores públicos brasileiros e noruegueses. $R A C$ Revista de Administração Contemporânea, 15(5), 815-833. https://doi.org/10.1590/S1415-65552011000500003

Cech, E. A. (2013). The self-expressive edge of occupational sex segregation. American Journal of Sociology, 119(3), 747789. https://doi.org/10.1086/673969

Chies, P. V. (2010). Identidade de gênero e identidade profissional no campo de trabalho. Revista Estudos Feministas, 18(2), 507-528. https://doi.org/10.1590/S0104-026X2010000200013

Cho, S., Kim, A., \& Mor Barak, M. E. (2017). Does diversity matter? Exploring workforce diversity, diversity management, and organizational performance in social enterprises. Asian Social Work and Policy Review, 11(3), 193-204. http://doi.org/10.1111/aswp.12125

Cochran, A., Hauschild, T., Elder, W. B., Neumayer, L. A., Brasel, K. J., \& Crandall, M. L. (2013). Perceived gender-based barriers to careers in academic surgery. The American Journal of Surgery, 206(2), 263-268. https://doi.org/10.1016/j.amjsurg.2012.07.044

Creswell, J. W. (2007) Projetos de pesquisa: Métodos qualitativo, quantitativo e misto. Porto Alegre: Artmed.

Cruess, R. L., Cruess, S. R., Boudreau, J. D., Snell, L., \& Steinert, Y. (2015). A schematic representation of the professional identity formation and socialization of medical students and residents: A guide for medical educators. Academic Medicine, 90(6), 718-725. https://doi.org/10.1097/ACM.0000000000000700

Departamento Intersindical de Estatística e Estudos Socioeconômicos (2017). A inserção da mulher no mercado de trabalho da região metropolitana de Fortaleza. Pesquisa de Emprego e Desemprego. Retrieved from https://www.dieese. org.br/analiseped/2016/2016pedmulherfor.html

Dubar, C. (2005). A socializaçâo: Construçâo das identidades sociais e profissionais. São Paulo: Martins Fontes.

Dubar, C. (2012). A construção de si pela atividade de trabalho: A socialização profissional. Cadernos de pesquisa, 42(146), 351-367. https://doi.org/10.1590/S0100-15742012000200003

Edmunds, L. D., Ovseiko, P. V., Shepperd, S., Greenhalgh, T., Frith, P., Roberts, N. W., Pololi, L. H., Buchan, A. M. (2016). Why do women choose or reject careers in academic medicine? A narrative review of empirical evidence. The Lancet, 388(10062), 2948-2958. https://doi.org/10.1016/S0140-6736(15)01091-0
Fine, C., Sojo, V., \& Lawford-Smith, H. (2020). Why does workplace gender diversity matter? Justice, organizational benefits, and policy. Social Issues and Policy Review, 14(1), 36-72. https://doi.org/10.1111/sipr.12064

Fitzsimmons, S. R. (2012). Women on boards of directors: Why skirts in seats aren't enough. Business Horizons, 55(6), 557566. https://doi.org/10.1016/j.bushor.2012.07.003

Franco, T., \& Santos, E. G. D. (2010). Mulheres e cirurgiãs. Revista do Colégio Brasileiro de Cirurgióes, 37(1), 72-77. http://dx.doi.org/10.1590/S0100-69912010000100015

Gazaway, S., Gibson, R. W., Schumacher, A., \& Anderson, L. (2019). Impact of mentoring relationships on nursing professional socialization. Journal of Nursing Management, 27(6), 1182-1189. https://doi.org/10.1111/jonm.12790

Hill, E., \& Vaughan, S. (2013). The only girl in the room: How paradigmatic trajectories deter female students from surgical careers. Medical Education, 47(6), 547-556. https://doi.org/10.1111/medu.12134

Hughes, E. C. (1958). Men and their work. Florence, MA: Free Press.

Lempp, H., \& Seale, C. (2006). Medical students' perceptions in relation to ethnicity and gender: a qualitative study. BMC Medical Education, 6(17), 1-7. https://doi.org/10.1186/1472-6920-6-17

Leslie, L. M., Manchester, C. F., \& Dahm, P. C. (2017). Why and when does the gender gap reverse? Diversity goals and the pay premium for high potential women. Academy of Management Journal, 60(2), 402-432. https://doi.org/10.5465/amj.2015.0195

Mason, M. A., \& Ekman, E. M. (2007). Mothers on the fast track: How a new generation can balance family and careers. Oxford: Oxford University Press.

McKimm, J., Silva, A. S., Edwards, S., Greenhill, J., \& Taylor, C. (2015). Women and leadership in medicine and medical education: International perspectives. In M. Tsouroufli (Ed.), Gender, careers and inequalities in medicine and medical education: International perspectives (pp. 69-98). Melbourne: Emerald Group.

Miller, K., \& Clark, D. (2008). "Knife before wife”: An exploratory study of gender and the UK medical profession. Journal of Health Organization and Management, 22(3), 238-253. https://doi.org/10.1108/14777260810883521

Minella, L. S. (2017). Medicina e feminização em universidades brasileiras: $\mathrm{O}$ gênero nas interseções. Revista Estudos Feministas, 25(3), 1111-1128. https://doi.org/10.1590/1806-9584.2017v25n3p1111

Oliveira, L. B., Cavazotte, F. S. C. N. de, \& Paciello, R. R. (2013). Antecedentes e consequências dos conflitos entre trabalho e família. RAC-Revista de Administraçâo Contemporânea, 17(4), 418-437. https://doi.org/10.1590/1806-9584.2017v25n3p1111

Pereira, J. B. C., \& Hanashiro, D. M. M. (2010). Ser ou não ser favorável às práticas de diversidade? Eis a questão. $R A C$ Revista de Administração Contemporânea, 14(4), 670-683. https://doi.org/10.1590/S1415-65552010000400007 
Póvoa, A. C. S., Maffezzolli, M. R., Pech, W., \& Silva, W. $\mathrm{V}$. (2017). A influência do gênero no processo decisório: $\mathrm{O}$ jogo do ultimato. RAC-Revista de Administraçâo Contemporânea, 21(4), 481-499. http://dx.doi.org/10.1590/1982-7849rac2017160152

Saraiva, L. A. S., \& Irigaray, H. A. R. (2009). Políticas de diversidade nas organizaçóes: Uma questão de discurso? RAERevista de Administração de Empresas, 49(3), 337-348. https://doi.org/10.1590/S0034-75902009000300008

Santos, C. (2005). A construção social do conceito de identidade profissional. Interaçôes: Sociedade $e$ as novas modernidades, 5(8), 123-144. Retrieved from https://www. interacoes-ismt.com/index.php/revista/article/view/145

Scheffer, M., Biancarelli, A., \& Cassenote, A. (2011). Demografia médica no Brasil: Dados gerais e descriçôes de desigualdades: Relatório de pesquisa. São Paulo: Conselho Regional de Medicina do Estado de Sáo Paulo, Conselho Federal de Medicina.

Scheffer, M. C., \& Cassenote, A. J. F. (2013). The feminization of Medicine in Brazil. Revista Bioética, 21(2), 268-277. https://doi.org/10.1590/S1983-80422013000200010

Scheffer, M., Biancarelli, A., \& Cassenote, A. (2015). Demografia médica no Brasil 2015. São Paulo: Departamento de Medicina Preventiva, Faculdade de Medicina da Universidade de São Paulo, Conselho Regional de Medicina do Estado de Sáo Paulo, Conselho Federal de Medicina.

Scheffer, M., Biancarelli, A., \& Cassenote, A. (2018). Demografia médica no Brasil 2018. São Paulo: Departamento de Medicina Preventiva, Faculdade de Medicina da Universidade de Sáo Paulo, Conselho Regional de Medicina do Estado de São Paulo, Conselho Federal de Medicina.
Schroen, A. T., Brownstein, M. R., \& Sheldon, G. F. (2004). Women in academic general surgery. Academic Medicine, 79(4), 310-318. https://doi.org/10.1097/00001888-200404000-00006

Seemann, N. M., Webster, F., Holden, H. A., Carol-Anne, E. M., Baxter, N., Desjardins, C., \& Cil, T. (2016). Women in academic surgery: Why is the playing field still not level? The American Journal of Surgery, 211(2), 343-349. https://doi.org/10.1016/j.amjsurg.2015.08.036

Shinyashiki,G.T., Mendes,I.A.C., Trevizan,M.A., \&Day,R.A.(2006). Professional socialization: Students becoming nurses. Revista latino-americana de enfermagem, 14(4), 601-607. https://doi.org/10.1590/s0104-11692006000400019

Spudeit, D., \& Cunha, M. V. (2016). O processo de socializaçáo na construção da identidade dos bibliotecários em Santa Catarina. Em Questão, 22(3), 56-83. https://doi.org/10.19132/1808-5245223.56-83

Vale,G.M.V.,Serafim,A.C.F., \&Teodósio,A.D.S.S.(2011).Gênero, imersão e empreendedorismo: Sexo frágil, laços fortes? $R A C$ Revista de Administração Contemporânea, 15(4), 631-649. https://doi.org/10.1590/S1415-65552011000400005

Zarshenas, L., Sharif, F., Molazem, Z., Khayyer, M., Zare, N., \& Ebadi, A. (2014). Professional socialization in nursing: A qualitative content analysis. Iranian journal of nursing and midwifery research, 19(4), 432-438. Retrieved from https://pubmed.ncbi.nlm.nih.gov/25183987/

Zauli, A. (2015). Reflexóes sobre diversidade e gênero. Brasília: Ediçóes Câmara. 


\section{Authorship}

\section{Isabelle Christine Oliveira dos Santos}

Universidade Federal do Ceará

Av. da Universidade, no 2431, Benfica, 60020-181, Fortaleza, CE, Brazil

E-mail address: isabelle.cos.23@gmail.com

(D) https://orcid.org/0000-0001-5514-9150

\section{Tereza Cristina Batista de Lima}

Universidade Federal do Ceará

Av. da Universidade, no 2431, Benfica, 60020-181, Fortaleza, CE, Brazil

E-mail address: tcblima@uol.com.br

(D) https://orcid.org/0000-0002-6594-4921

\section{Luis Eduardo Brandáo Paiva*}

Universidade Federal do Ceará

Av. da Universidade, no 2431, Benfica, 60020-181, Fortaleza, CE, Brazil

E-mail address: edubrandas@gmail.com

(D) https://orcid.org/0000-0002-5036-6823

\section{Davi Sampaio Marques}

Universidade Federal do Ceará

Av. da Universidade, no 2431, Benfica, 60020-181, Fortaleza, CE, Brazil

E-mail address: davi.marques@ufc.br

(D) https://orcid.org/0000-0001-5946-0317

\section{Elidihara Trigueiro Guimarães}

Universidade Federal do Ceará

Av. da Universidade, no 2431, Benfica, 60020-181, Fortaleza, CE, Brazil

E-mail address: elytrigueiro@yahoo.com.br

(D) https://orcid.org/0000-0003-0143-2289

* Corresponding Author

\section{Funding}

The authors reported that there is no financial support for the research in this article.

\section{Conflict of Interests}

The authors have stated that there is no conflict of interest.

\section{Copyrights}

RAC owns the copyright to this content.

\section{Authors' Contributions}

$1^{\text {st }}$ author: conceptualization (equal); data curation (equal); formal analysis (equal); investigation (equal); methodology (equal); resources (equal); software (equal); validation (equal); visualization (equal); writing-original draft (equal).

$2^{\text {nd }}$ author: conceptualization (equal); investigation (equal); project administration (equal); supervision (equal); validation (equal); visualization (equal).

$3^{\text {rd }}$ author: conceptualization (equal); formal analysis (equal); methodology (equal); supervision (equal); validation (equal); writing-original draft (equal); writing-review \& editing (equal).

$4^{\text {th }}$ author: conceptualization (equal); software (equal); validation (equal); visualization (equal); writing-review \& editing (equal).

$5^{\text {th }}$ author: methodology (equal); supervision (equal); visualization (equal); writing - review and edition (equal).

\section{Plagiarism Check}

The RAC maintains the practice of submitting all documents approved for publication to the plagiarism check, using specific tools, e.g.: iThenticate.

\section{Peer Review Method}

This content was evaluated using the double-blind peer review process. The disclosure of the reviewers' information on the first page, as well as the Peer Review Report, is made only after concluding the evaluation process, and with the voluntary consent of the respective reviewers and authors.

\section{Data Availability}

All data and materials have been made publicly available through the Harvard Dataverse platform and can be accessed at:

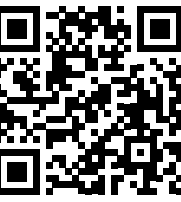

Isabelle Christine Oliveira dos Santos; Tereza Cristina Batista de Lima; Luis Eduardo Brandão Paiva; Davi Sampaio Marques; Elidihara Trigueiro Guimaráes, 2020, "Replication Data for: Professional Socialization from the Perspective of Female Surgeons: Challenges and Career Achievements", Harvard Dataverse, V1. https://doi.org/10.7910/DVN/CTKEJZ

RAC encourages data sharing but, in compliance with ethical principles, it does not demand the disclosure of any means of identifying research subjects, preserving the privacy of research subjects. The practice of open data is to enable the reproducibility of results, and to ensure the unrestricted transparency of the results of the published research, without requiring the identity of research subjects.

RAC is a member of, and subscribes to the principles of the Committee on Publication Ethics (COPE) for scholarly publication 